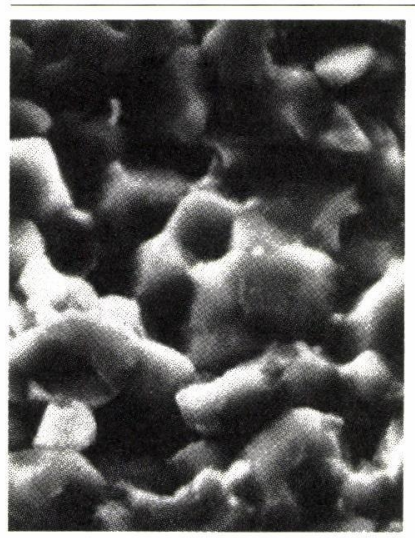

\title{
WSI かハイブリッドか
}

WSI or Hybrids?

標題の「WSIかハイブリッドか」は編集委員会から与 えられたテーマである。「モノリシックかハイブリッド か」ならいざ知らず，一気にWSIに飛んでいることにま ず奇異な感じを持つ読者が多いに違いない。これはちよ うど「アメリカかソ連か」と対比すべきところを「二ュ ーヨークかソ連か」に置き換えたようなもので，比較検 討するためのモ/サシが定まらないのである。それゆえ 執筆を再三固辞したが, 中村編集委員長の強い勧めによ り敢えて筆をとる次第である。

\section{W(Wafer) SI と W(Wide) SI}

WSI，すなわち Wafer Scale Integration という言葉 を耳にしてすぐ思い起こすことは，ハイブリッドの分野 でも，かつてWSI という提案があったことだ。ただしこ の場合はWide Scale Integrationの略で, 名付けの親は 当時東京三洋電機の三浦敬男氏（現三洋電機取締役）で ある。同社では1968年に通産省の工業化試験プロジェク トの一環として「線形広範囲集積回路に関する工業化試 験」を受託, 論理回路の LSI に対応する線形回路の大集 積化を厚膜ハイブリッド技術を駆使して央現した（大信 号と小信号の各ブロックを 1 枚の基板上に搭載した八イ ブリッドICはその一例)。Wide Scale Integration はこ の種のハイブリッドに付せられたネーミングである。

このことが示すように，本来のWSIもハイブリッド も最終的には高集積・多機能化を目指していることに変 わりはない。その意味では同じく富士山の頂上を目指し ているのだが, ただ御殿場口から登るのと吉田口から登

${ }^{*}$ Yukio Shimura

工. 業調查会/Kogyo Chosakai Publishing Co., Ltd.
志村 幸雄*

るのとでは登り方が違うように，目的に対する対応の仕 方がずいぶん違うのである。

しかし，それにもかかわらずWSI と八イブリッドと の相関をある種のア十ロジー(類推) で捉えたくなるよ うな衝動にかられるのは，一定の基板上に素子(ないし は回路）があたかもアイラント（島）のような形で分散 し，それらが相互結線されることによりシステムないし はサブシステム的な機能を体現しているからだ。一うの 基板は半導体であり, 他方の基板は絶縁体であるが, 技 術の概念としては相似のものである。

いささか大胆な言い方をすれば, WSI もハイブリッド も，もともとはいわゆるモノリシックICの代替ないし はアンチテーゼ (反対命題) として考案され，その限り で共通項のものと言えよう。

振り返ってWSIの原型であるDiscretionary Wiring (選択配線) 万式が米 TI 社によって提案されたのは 1960 年代半ばのこと。当時の IC（いわゆるSSI）はたかだか 4 ゲート程度のもので, できうればその数倍から数十倍 のチップの出現が望まれていた。だが，当時の加工技術 の水準では望むべくもなく，複数のユニットセル(チッ プに相当）の組み合わせによりそれを実現しようとした。

Discretionary Wiring 方式ではまず複数個の単位基 本回路（たとえばゲート）をユニットセルとし，1枚の ウェ八上に格子状につくる。ここまでは通常のICと同 じで, ICの場合はこれをユニット七ル毎に切り離してパ ッケージに封入するのであるが，これを切り離さずにウ エハの中で相互配線（多層配線）を行う。この場合，ウ エ八上に形成された100 200個の工ニットセルは全部が 良品とは限らない。そこで多層配線を行う前に試験機に かけて良否を判別し，良品の座標を計算機に記憶させる。 同時に製造しようとする回路接続の情報を計算機に与え

HYBRIDS 
てやると，計算機は両方の条件を満足するような配線パ ターンを発生し, それに従って自動露光装置がウェ八上 にパターンを焼き付ける。

これでわかるように Discretionary Wiring 方式は, 今 日のWSIの原点的な存在に当たるものだが，少なくと も，この時点でこの種の手法が考察された背景には, SSI レベルにとどまっていたモノリシック IC 技術の限界を, MSI，LSI 乞と自己増殖的な技術で置き換えるのではな く, SSIの複合化(いわばマルチチップ化)によって解決 しょうとしたことだ。WSI ではその解決手段を 1 枚のシ リコンウェハ上に求めたが，八イブリッドでは同種のこ とを厚膜，薄膜技術を基盤にしながらセラミック基板上 に求めた。その意味で SSI $\rightarrow$ MSI $\rightarrow$ LSI への技術展開 を垂直指向とすれば, WSI ないしハイブリッドへの技術 展開は前者の技術を基点にした水平指向の拡がりと言え よう。現に LSI, 超 LSI 時代を迎えた今日では, WSI も ハイブリッドも LSI, 超 LSI (技術)を積極的に取り込み ながら，集積度や機能の増大を図っている。

\section{WSI とハイブリッドの競合}

WSI とハイブリッドとの間には技術的に見て共通の 概念があるだけに，逆に競合関係の技術と言えなくもな い。WSI 技術が未確立の今日の時点では少なくても, 将 来はそういう場面が多くなるかも知れない。

その 1 つとてメモり関係の適用例をあげると，富士 通は昨年, 200Mビットのウェハスケールメモリを発表し ている。これは 6 インチのシリコンウェハ上に標準の 1 Mビット DRAM を202個配列し，それぞれをリード，ラ イトの入出力線で結線したものである。この場合, ウェ 八上の DRAM は欠陷発生のため本来なら全数使用でき るわけではないが, 独自の久陥回避技術を用いることに より200Mビットに近い高歩留りを得ている。

この種のメモリシステム技術としては，すでにハイブ リッド技術を基盤にしたメモリモジュールが実用化され ている。一例として東芝では電子スチルカメラ向けのも

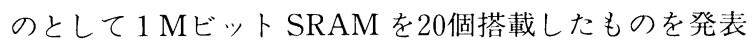
しているが,これはガラスエポキシ基板に $\mathrm{TAB}$ 技術を 用いて実装している。

同じメモリシステムでも WSI 的アプローチと八イブ リッド的アプローチとの間には，さまざまな利害得失が 考えられる。WSIの利点としては, (1)高集積化に向いて いる，(2)回路間の相互配線長を短くでき高速化が可能, (3)組立工程の削減によりコストダウン(特に組立コスト) が可能, などがあげられる。しかし, 同時に欠点として, (1)大面積上のデバイスであるため欠陥の発生からまぬが
れられず，圥長技術，欠陷回避技術といった余分な技術 的対応ができ，(2)ウェ八全体が動作した場合，高い発熱 量が予想され，冷却技術が必要，(3)大面積で薄板のシリ コンウェ八を用いているため, 実装面でメカニカルスト レスや熱澎張によるストレスの発生からまめがれられな い, などの問題が残されている。

ハイブリッドの利点，欠点はほぼWSIのそれと裏腹 のものであろう。しかし，ハイブリッドアプローチの利 点で見落としてならないのは，モノリシックに対するハ イブリッドの長所としてしばしば指摘されるように，回 路の変更が比較的容易なため多様なニーズにそれだけ柔 軟に対応できることである。

\section{WSI とハイブリッドの融合}

相異なる文化と文化とが接触して新しい文化が創出さ れるように，技術の世界でも相対立する技術が接近，融 合し，より高次の新しい技術を生み出す。ハイブリッド 技術とWSI 技術との間にもこのような動きが陌間見ら れる。ハイブリッド WSI (H一WSI) がその例だ。

$\mathrm{H}$-WSI は, WSI があくまで1枚のシリコンウェ八上 に回路を集積した，モノリシックアプローチの一手法で あるのに対して，シリコンウェ八を配線基板用として考 え，これに一定の回路機能を持った LSI チップを搭載接 続する実装手法である。基本となる技術にはモノリシッ ク技術を用いているが，実装形態としては八イブリッド 技術そのものである。この場合，シリコンウェハプロセ スによる配線技術を使用しているため容易に高密度配線 が得られ，したがってチップの高密度実装が可能になる。 また，LSI チップ一基板間接続部における熱ストレスの 発生についても，同一材料を使用しているためほとんど 問題にならない。このような利点が買われて, ここ数年, 日米の主要メ一カーでの取り組みが始まっている。

AT\&Tレベル研究所では,この種の H一WSIを AVP (Advanced VLSI Package) と呼んで開発中である。プ ロトタイプモジュールの1つとして CPU, MMU(Memory Management Unit), MAU (Math Accelerator Unit）の 3 チップを搭載したものがある。シリコン基板 側には信号ラインが 2 層構造で配置されており，最小線 幅は $10 \mu \mathrm{m}$ である。また,バイパスコンデンサが基板表面 部分に内蔵されている。基板サイズは $13 \times 13 \mathrm{~mm}$ で, LSI チップははんだバンプで構成される。

現時点ではウェハスケールというイメージに程遠いが, 近い将来には文字通りChip on wafer とでもいうものが 実現するに違いない。 